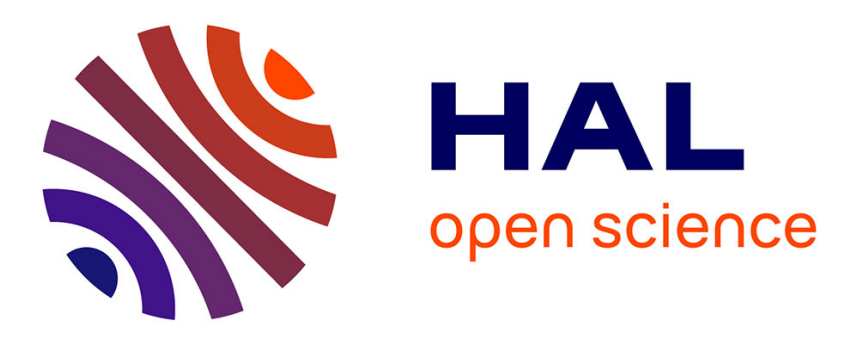

\title{
Whom we should blame for bad e-book? (sociological perspective of evaluation, selection and reception of e-book)
}

\author{
Nebojsa Lujanovic
}

\section{To cite this version:}

Nebojsa Lujanovic. Whom we should blame for bad e-book? (sociological perspective of evaluation, selection and reception of e-book). ELPUB 2020 24rd edition of the International Conference on Electronic Publishing, Apr 2020, Doha, Qatar. 10.4000/proceedings.elpub.2020.10 . hal-02544829

\author{
HAL Id: hal-02544829 \\ https://hal.science/hal-02544829
}

Submitted on 16 Apr 2020

HAL is a multi-disciplinary open access archive for the deposit and dissemination of scientific research documents, whether they are published or not. The documents may come from teaching and research institutions in France or abroad, or from public or private research centers.
L'archive ouverte pluridisciplinaire HAL, est destinée au dépôt et à la diffusion de documents scientifiques de niveau recherche, publiés ou non, émanant des établissements d'enseignement et de recherche français ou étrangers, des laboratoires publics ou privés. 


\title{
Whom we should blame for bad e- book? (sociological perspective of evaluation, selection and reception of e-book)
}

\author{
Nebojsa Lujanovic
}

\section{Sociology of literature and the question of reader}

1 It's common understanding that sociology of literature deals with ideological (or, more general, contextual) implications of producing and reading texts. According to Escaprit (1970), sociology of literature treats literature as a phenomenon which is related to art as much as trade, politics and politics. It is impossible to define all relevant factors and combine them in one definition. Simply, sociology of literature understands that literature is happening in a certain time and space, not in a vacuum (as some traditional approaches suggest). Further, every segment of literature is also process defined by its context: writing, production of literature, distribution, reading and evaluation. Here, we are especially interested in reading and evaluation: who and how reads e-books today, and which set of literary values uses as his orientation.

Question of values leads us to question of pluralism of postmodern age, with one crucial point. Today, when we have domination of ideology above all ideologies, commercial culture, there is a need to think about the reader in that context. Publishing is a part of the cultural industry, the industry is related to categories of investment and profit, and we have to combine that with the relation of the literary value and status of (literary) art. In (post)capitalist society, the principle of profit is still dominant. The culture is connected to profit and industry in so many ways that we can discuss it only in the context of cultural industry. The result of that merging is a new kind of economy, the creative industry (by the way, the fastest-growing industry in the world) (Tomašević, 2015). Thus the e-book is undefined content which becomes defined and recognized by 
art only in the eye of the reader who has his specific, in postmodern era pluralistic and unstable, values to rely on. And, after all, a book is also the product made for making a profit, so the measure of its profitability is also one of that 'values'. There are no more ideological censors who will coordinate aesthetic values and publishing politics with dominant system od values. Instead, we have censors who estimate their profitability as important criteria for publishing.

3 Someone would say that e-publishing doesn't have those problems because everything is accessible on the net. He would say that there is no limits, censorship and question of profit (free and low priced). But, if we give a closer look at different platforms for distribution e-books, things are more complicated. We can't ignore the situation that publishers are in the mercy of a few subjects who are the owners of platforms for presenting and selling e-books (Clark and Phillips, 2017: 17-18). A digitalized book is a universal operating system with no limits, accessible to anyone. But, to be offered, it must be a part of someone's platform. And we are coming back to the question of profit. With keeping in mind heterogeneous field of e-market: from American version to Croatian one. There are big differences in the level of productivity, popularity and profitability. But, we will look at the Croatian example later, still keeping in mind the reader as a significant factor.

Escarpit (1970: 21) defines literature as a phenomenon which appears in three forms: as a book, reading and literature. This means that we can talk about literature as a physical object, the result of consuming/understanding certain content, and as a work of art. The boundary between those categories isn't always clear, but it illustrates the complexity of the subject and gives possible directions to choose in further discussion. We are choosing consuming and understanding, so this paper stresses the relation between reader and e-books, especially (im)possibility to form their own set of values (to rely on) or an external one (to use instead). Or, what kind of readers with what type of taste and habits consume e-books (using the example of Croatian researches and their attitudes on reading e-books). The problem of literary values (set of rules or principles what kind of literature is valuable as a piece of art) is mentioned several times in this theoretical introduction with reason. Modern theorists claim that there is no universal rules and steps to define what is valuable art, or what is a good book. Such principles are the result of 'the spirit of the age', which means that every age has its art (Schücking, 2001). Doesn't mean that we have sort of spontaneous and democratic process which leads us to them. The question of power, as Foucault (1994) suggests, has a significant role in it, but that is for a different discussion.

We have to narrow our discussion to this: who stands between e-book and its consumer/reader? Which system od filtering, quality checking, mechanism of recommendation or critical evaluation? What happens in the literary sphere if we suggest that there is no effective system between those two positions? The attempt of understanding this problem forced us to explore several different processes: the specificity of e-publishing, the system of evaluation, the outcomes of research on buying and reading e-books (based on a Croatian case study), but also the main characteristics of our cultural epoch. 


\section{E-publishing (generally and Croatian example)}

6 'Digital revolution' became the theme of countless conferences and articles, mostly keeping an optimistic attitude about every aspect of it. Fast technological changes, the appearance of the internet and its possibilities first affected the music industry and then spread to all creative industries, including publishing. By the late 1990s, many publishers were pouring millions of dollars into electronic publishing projects which digitalized books and made it available in different formats (Thompson, 2012: 313). But, till now, the life of e-books has its ups and downs. After a good start in the first decade, already in the 2000s, this new economy is slowing down, and investors lower their expectations. The E-book didn't make paper book disappeared, far from that. Still, it didn't also make a significant breakthrough yet, and we have no answer why (high prices of books and reading devices, publishers don't put enough effort to offer more content on the electronic form) (Thompson, 2012: 314-315).

7 The fact is that e-publishing still keeps a significant percentage in the Asian and American markets, but very low in other peripheral markets such as Croatian. There is no need to discuss about advantages and possibilities of e-books, all those countless conferences and articles already did that. This slowing down is good opportunity to think about problems: why is developing of that kind of publishing so uneven in different markets, why it shows negative trends in some cases (Croatian example) and what to do with the problem of values or system of selecting and filtering the content.

8 We are talking about the market of almost 4 million inhabitants, switched from a combination of communism and market to neoliberal market thirty years ago. After that turning point, Croatian society and industry started with the transition phase, kind of permanent unfinished process that still has a chaotic feel to it. Because it was interrupted by war followed by the global economic crisis. In that kind of conditions, it had to go through three levels of transition: changing owner structure (state companies became private, big became small), changing technological backup and relocation (shifting to commercial production, catching global trends) (Tomašević \& Kovač, 2009: 267-268).

That's the reason why rashly rising of the publishing industry (multiplying average copies per book, number of small publishers, opening big bookstores at the beginning of the millennium) turned very soon to collapse of the publishing business. Many of the big bookstores were closed just after five or more years of business; two big publishers went bankrupt; other middle publishers decrease their production; average publishing rates and sold bestseller's copies are 50\% lower than fifteen years ago, and so on. In those conditions, the development of e-publishing in Croatia is very slow. Besides the general economic situation, the study data demonstrate that technical details and taxes policy, but also habits of the readers are among the other significant factors which make it even slower.

10 Croatian publishers have been very cautious with investing in digital distribution. The numbers are suggesting that they invest very little time and sources to promote their digital editions, maybe trying to delay the process as much as possible, still sticking to traditional publishing methods (Velagić \& Pehar 2013). Before discussing the specific data about Croatian e-publishing, it is necessary to stress that the number of applications offering books in (or translated to) Croatian language are very few. In addition, the high taxes on e-books, and the high prices of e-books are among the 
argumenta that are usually mentioned as the main problem for their buyers. We rely on Croatian Book Market research from 2018. (has more parameters than one from 2019.), made by Market Research Agency. ${ }^{1}$

11 Talking about the book in general, the public and the media were shocked by first research data: just about the half of Croatian citizens read a book in one year, mostly borrowed from libraries or a friend). Further, $25 \%$ of Croatian citizens bought a book last three months (in comparison, $8 \%$ less than fifteen years ago, as an argument for crushing down the publishing industry mentioned earlier). The answers to the question why they don't read is quite disturbing: $61 \%$ of those who do not buy or read books said that they are not interested in books at all. In that kind of social atmosphere, it is hard to expect optimistic numbers related to e-book as a relatively exotic spectrum of publishing and reading. Although 70\%of examinees have some kind of electronic device (as a technical possibility to read e-book), only $15 \%$ actually read e-books. The rest of them said that they read mainly newspapers, magazines and different articles on their devices. Age structure shows that buyers of e-books are mostly young people (about 24 years old), and questions about content indicates that they are interested in popular and cheap literature in genres. Considering the ways of buying books, a very high percentage still prefers buying books in bookstores or newspaper stands directly, only a tenth of them use the internet for that. Popular books (bestsellers with aesthetic quality) are still expensive, even in the electronic form, and a very small percentage of popular titles are available in that form. So, in conclusion of Croatian example, there are very few buyers of e-books, and they usually buy popular books with lower quality and price.

Two types of task come from that conclusion. We could go into details exploring the question of the low rate of e-book buyers. Or we could deal with the problem of consumed content. If we chose the second one, the fact that e-book buyers consume mostly lower-quality books leads us to our central question, inspired exactly by these results - are there a system of values or mechanisms of recommendations to rely on before choosing e-book? Or, if there are bad e-books, whom we should blame?

\section{The cultural frame - a problem of value and criteria}

The postmodern tendencies influence the social-cultural context of our subject. The ones that concern us are relativization of literary values and reduced possibility to discuss about it. If we consult a few postmodern theorists, we will discover that most of them agree that our culture cancelled all hierarchies, destabilized all centres and foreclosed all binary oppositions. With so many tendencies to free repressed voices (gender, ethnical, marginal, and so on), we destroyed different kinds of ideological centres of power. By the way, what happened also is the collapse of known systems of values and a new landscape of ruins with no solid point at all (Milner, 1996; Harvey, 1999).

The new cultural situation being captured within the famous statement 'anything goes', means that we must think about how it reflects on the question of literary value. That kind (or any other) of value can't be established, and no critical statement formed because we do not have a wider value system to refer. Besides, we are in a culture where pictures dominate over notion; that means that everything is going on the surface where the recipient only gets a pictorial short-term reflection of the subject, 
without deeper consideration (Solar, 2009). In that package goes society of the spectacle and culture of the kitsch, both with stressed visual dimension (Debord, 1999). Shortly, we live in the epoch of superficiality, chaos and fragmentation. The result is disorientated reader with the trouble of selecting what is valuable and important in the market of goods, information and artistic works. At the end, we have marketing strategies which use that situation to make a profit (from the publishing industry and others). Therefore, publishers are capable of selling any book as a new classic or masterpiece; there is no critical boundaries to stop them (Solar, 2011).

Unsuited circumstance is hyperproduction of literary works. We are disoriented more than ever, and overwhelmed by goods more than ever, at the same time. Readers were never surrounded with that amount of information and books in the history of civilization. That comfort is provided by modern technology, but also cultural development that includes a high rate of publishing production and distribution. On the other side, we have standard growth which includes a great number of people that have literate abilities and the possibility to buy new books. So, the modern reader has a wide range of abilities, but still finds it hard to struggle with all those books that wait for his/her attention.

Yuval N. Harari (2017) also could be included in discussion with his statement that today you are in greater danger to die from obesity than hunger. Hyperproduction is not a matter of books and bad publishing policy; it is in the core of the modern world. Harari expresses pretty dark predictions about future founded on the eternal growth. Because of that hyperproduction, we have all sorts of problems: ecological problems, nearness of growth limit, crises of humanism, separating intelligence from consciousness, dominating technicism and dataism, and so on. The fact that plenty of food and material goods also includes plenty of information, books and works of art without a clear system of values is only one of the problems.

That leads us to the central problem of the paper, inspired by Michael Bhaskar's book of 2018 called The power of selection in a world of excess. He stressed the difficulties which come from the fact that we live in this kind of hyper-productive culture. Bhaskar claims that we are now victims of wrong postulates and aims. We founded our civilization on the belief that we must always produce, be productive, without thinking about limited sources. Also, we have one myth that dominates in all our spheres of life, and that's one about creativity. To be modern, to be interesting, popular, and, after all, to be human, you must be creative. Nobody explains us, claims Bhaskar, what to do with that million and tenth version of picture, tool or device. Because of that myth, we produced more in the last few decades than in the last few centuries. The industrial society was focused on how to produce goods; our postindustrial society is focused on how to produce needs because we already have everything that is necessary for our basic needs. This is the point where our problems start. Who will select and according to which criteria in all that jungle of produced goods?

\section{Who will select?}

Bhaskar has a very picturesque example in his study: the modern reader has more information on his palm in one moment than an ancient reader in the whole Alexandrian library. The big question is: what kind of information? Is this information sorted or selected? Is there any kind of filter before they start their circulation? Whose 
responsibility is to filter or select? Who has that power and possibility? These are questions without an answer for Bhaskar, but he is the first one that sets them as an important problem of our culture. He explains the whole situation on the example of museum curators. Museums have to deal with a great number of applications for exhibitions; curators have to discern between paintings, installations with pipes, lonely toilet seat on the floor and a pile of torn paper. Which one is worthy of people's attention? The curators must decide; that's why their job is the most wanted and very well paid. Bhaskar claims that their position is important because they are the only filter; the only criterion that stands between the producer and the consumer. So, he predicts, the job of curators/selectors in all cultural fields will be the most important one in the future.

To sum up: we have relativization of the literary taste, lack of evaluation skills, hyperproduction, plenty of cultural goods and development of e-publishing. Coming back to the main question: who will filter, select and evaluate e-books? Traditional publishing had a certain mechanism of selection and other circumstances that kept under control commercialization and hyperproduction of the art. First, book production was more expensive; hence the criterion of selection what will be published were more rigid. Second, it had to rely more on subvention of the state (meaning, commissions of professionals who evaluate applications). Third, buying in bookstores or taking books from libraries included mediators (booksellers and librarians) and communication with them with more interactions (mediators get feedback from customers, give them advice). Fourth, the lower rate of production enables, more or less, critics to keep track of new books and write about it in media sections which were a reliable source of information.

When we focus on e-publishing, we have certain factors that make all situation more complicated (considering problem of evaluation and selection): lower costs of publishing, very big numbers of published books, excluding mediators, cancelling book sections in mainstream media, not well-paid critic articles and so on. Where is Bhaksar' s curator to help us? When it comes to e-books, we can't put a person as a mediator. Suppose that it should be sort of evaluation system, software application or organized net of user/experts. Discussing it means that we must analyze the e-publishing sector to look if there is a similar system already in use, or at least one that is approximately efficient as we expect.

\section{Book Recommendation systems?}

21 That main question leads as to the main task: how to ensure the system of filtering in epublishing? It is not just the biggest challenge for all of us included in books in reading. It is also, as we have seen from Bhaskar's examples, the question of the cultural epoch that we are living. The whole culture is facing with that task. But we will stick with our area. Looking for similar attempts to select or recommend e-books, we can find specific private initiatives, enthusiastic individuals who create programs based on a few questionable factors. We have no central points or systems refer to, instances to rely on without a doubt. So few individuals are trying with new ideas, with no significant result, but worthy of our attention as first steps to deal with the problem that we elaborate in this paper. 
example that we can give a closer look is the Book Recommendation System by Chhavi Saluja. ${ }^{2}$ She explained it in the article 'My Journey to building Book Recommendation System'. She uses rating dataset form pages where readers rate most popular books published in the specified period. Then, she builds algorithm to collect and sort that data (considering users who have rated at least 100 books and books which have at least 100 ratings). The algorithm can recommend books for user-based or item-based approach (based on selected approach and metric combination). It is not easy to understand all described steps for those who are not common with programming, but it is possible to notice the main approach.

Analyzing those steps, we can see that they rely on two main factors: interest in the specific book (formed by the number of clicks) and review of the marked subject (selected by numbers of written reviews). In both cases, we are talking about quantity, not quality. Consider the most rated books, the most active readers and the biggest average rating. In this case, we assume plenty of questionable elements: that all sorts of genres are represented, that the most of readers whose rating we are taking have necessary critical skills, that most of the books are pointed not because of their clever marketing strategy, but their quality and so on.

Bhaskar is discussing the same problem in his book. All available systems of recommendations (not just for e-books) are based on quantitative metrics. They take information about the type of content you click the most, scan your taste, and, according to that data, offer the next product that is most likely that you will read or consume. That means the reader won't get a recommendation of a good book, but a book that is more similar to one that $\mathrm{s} /$ he already read. How will $\mathrm{s} / \mathrm{he}$ get to a highquality book? How will s/he develop a book taste? With the described system of recommendation, s/he will be trapped in the circle of the same sort of literature. Obviously, the current systems do not solve our main problem. So, the conclusion is that we are in a chaotic situation where fast technological development is not followed by corresponding theoretical elaboration. Until then, we are left to find our own solutions in the noisy crowd of new books.

\section{BIBLIOGRAPHY}

Appignanesi, Richard \& Chris Garratt. Postmoderizam za početnike, 2002. Zagreb: Jesenski i Turk.

Clark, Giles \& Angus Phillips. O nakladništvu iznutra, 2017. Zagreb, Hrvatska sveučilišna naklada.

Bhaskar, Michael. Umijeće izbora u svijetu preobilja, 2018. Zagreb: Naklada Ljevak.

Debord, Guy. Društvo spektakla, 1999. Zagreb, Arkzin.

Escarpit, Ropert. Sociologija književnosti, 1970. Zagreb: Matica hrvatska.

Foucault, Michel. Znanje i moć, 1994. Zagreb, Nakladni zavod Globus.

Harari, Yuval Noah. Kratka povijest sutrašnjice, 2017. Zagreb: Fokus. 
Harvey, David. The Condition of Postmodernity. Oxford, Blackwell Publishers Ltd, 1999.

Jelušić, Srećko. Ogledi o nakladništvu, 2012. Zagreb: Naklada Ljevak.

Milner, Andrew. Literature, Culture and Society, 1996. New York, New York University Press.

Schücking, Levin L. Sociologija oblikovanja literarnog ukusa, 2001. Zagreb: Dora Krupićeva.

Solar, Milivoj. Nakon smrti Sancha Panze (eseji i predavanja o postmodernizmu), 2009. Zagreb: Naklada Ljevak.

Solar, Milivoj. Kritika relativizma ukusa (predavanja o ukusu, moralu i poetici), 2011. Zagreb. Matica hrvatska.

Thompson, John B. Merchants of culture. Publishing business in the twenty-first century, 2012. London: Penguin book.

Tomašević, Nives. \& Miha Kovač,. Knjiga, tranzicija, iluzija, 2009. Zagreb: Naklada Ljevak.

Tomašević, Nives. Kreativna industrija i nakladništvo, 2015. Zagreb, Naklada Ljevak.

Velagić, Zoran i dr. Elektroničko nakladništvo, 2017. Zagreb: Naklada Ljevak.

Velagić, Zoran \& Franjo Pehar. "An overview of the digital publishing market in Croatia”. Libellarium, VI, 1-2, 2013, pp. 55-64.

\section{NOTES}

1. https://issuu.com/modernavremena/docs/prezentacija_no knjige_23.04.2018. (1.3.2020.g.)

2. https://towardsdatascience.com/my-journey-to-building-book-recommendation-

system-5ec959c41847

\section{ABSTRACTS}

From the perspective of Sociology of literature, this paper sets the question of what happens with communication and reception issues in the context of e-publishing, considering the cultural situation of lacking critic methods and established values? Related to e-publishing, the precise question is: how to set the reliable system of filtering e-books on the net? The paper discusses the main obstacles in that process and analyzes a few individual attempts to set that kind of mechanism. Besides technical improvements which will be mainly discussed on the EIPub Forum, this paper aims to motivate us to point some theoretical issues considering the problem of evaluation and reception as part of literary communication.

\section{INDEX}

Keywords: postmodern culture, e-publishing, value system, selection, book recommendation systems 
AUTHOR

NEBOJSA LUJANOVIC

Department of Culture, Media and Management The Academy of Arts and Culture in Osijek

Osijek, Croatia

nlujanovic@aukos.hr 